\title{
Impact of soil drought on sap flow and water status of evergreen trees in a tropical monsoon forest in northern Thailand
}

\author{
Tomonori Kume ${ }^{\text {a,b,* }}$, Hideki Takizawa ${ }^{c}$, Natsuko Yoshifuji ${ }^{\text {b,f }}$, Katsunori Tanaka ${ }^{\text {, }}$, \\ Chatchai Tantasirin ${ }^{\mathrm{e}}$, Nobuaki Tanaka ${ }^{\mathrm{b}, \mathrm{f}}$, Masakazu Suzuki ${ }^{\mathrm{b}}$ \\ ${ }^{a}$ Kasuya Research Forest, Kyushu University, Sasaguri, Fukuoka 811-2415, Japan \\ ${ }^{\mathrm{b}}$ Graduate School of Agricultural and Life Sciences, The University of Tokyo, 1-1-1 Yayoi, Bunkyo-ku, Tokyo 113-8657, Japan \\ ${ }^{\mathrm{c}}$ College of Bioresource Science, Nihon University, 1866 Kameino, Fujisawa, Kanagawa 252-8510, Japan \\ ${ }^{\mathrm{d}}$ Frontier Research Center for Global Change, Japan Agency for Marine-Earth Science and Technology, \\ 3173-25 Showamachi, Kanazawa-ku, Yokohama, Kanagawa 236-0001, Japan \\ e Department of Conservation, Faculty of Forestry, Kasetsart University, Chatuchak, Bangkok, Thailand \\ ${ }^{\mathrm{f}}$ Japan Science and Technology Agency/CREST, 3-4-15 Nihonbashi, Chuo-ku, Tokyo 103-0027, Japan \\ Received 3 March 2006; received in revised form 15 September 2006; accepted 16 October 2006
}

\begin{abstract}
Hill evergreen forest is the dominant vegetation type in northern Thailand. In this region, there is higher atmospheric evaporative demand and lower soil moisture during the 5- to 7-month dry season than in the rainy season under influences from Asian monsoons. In an earlier study we revealed that canopy-scale transpiration is actively maintained even during the latter part of the dry season in hill evergreen forest. However, the impact of soil drought on tree water use was not investigated. To clarify the ecohydrological processes at this site, we used individual tree-scale measurements during a 2-year period to base our examination of whether limited water use in individual trees is caused by soil drought in the latter part of the dry season. Sap flow and water potential measurements were conducted in four evergreen trees, two large emergent trees 29.8 and $25.4 \mathrm{~m}$ high, and two smaller understory trees 4.8 and $1.4 \mathrm{~m}$ high.

The amount of rainfall preceding the late dry season of 2004 was significantly less than that preceding the late dry season of 2003 . Although a distinct decrease in sap-flow velocities in individual trees due to soil water stress was not found in the late dry season of 2003, it did become comparatively apparent in the late dry season of 2004; ranging from 10 to $40 \%$ for a given atmospheric evaporative demand. Furthermore, the reductions in sap-flow velocities and predawn stem-water potential were most significant in the smallest tree. The recovery of sap-flow velocities and water potential in the smallest tree after irrigation confirmed that the reductions in sap-flow velocity and predawn stem-water potential in the smallest tree were caused by soil drought. These results suggest that shallower roots could be reason for the significant decrease in water use in the smallest trees. The deeper roots of larger trees could be the reason for the reduced impact of soil drought on water use in larger trees, and canopyscale transpiration might be maintained by larger trees, even in an unusually severe drought. These possibilities provide a new insight for management of evergreen forests under Asian monsoon influences.
\end{abstract}

(C) 2006 Elsevier B.V. All rights reserved.

Keywords: Evergreen forest; Asian monsoon; Sap flow; Water potential; Soil water stress

\section{Introduction}

An estimated $65 \%$ of forests in Thailand have been converted to other land uses within the last 30 years (Hirch, 1987; Myers, 1994). Such regional land-use changes can have an influence on regional and global water balance

\footnotetext{
* Corresponding author at: Kasuya Research Forest, Kyushu University, Sasaguri, Fukuoka 811-2415, Japan. Tel.: +81 92948 3101;

fax: +81929483119.

E-mail address: kumett@forest.kyushu-u.ac.jp (T. Kume).
}

through a change in evapotranspiration (e.g., Kanae et al., 2001; Zhang et al., 2001; Bruijnzeel, 2004; Mabuchi et al., 2005). Furthermore, drying trends due to marginal decreases in rainfall and to a greater frequency of ENSO events have been pointed out in this region (Wang and Weisberg, 2000; Malhi and Wright, 2004). Thus, to assess possible impacts on forests ecohydrological processes of drought due to climate change or inter-annual dry sequence coinciding with ENSO events, it is important to understand the evapotranspiration in response to soil water stress in typical forests in the regions. 
A hill evergreen forest is a mountainous forest and is dominated by the Fagaceae and Lauraceae plant families, the dominant vegetation type in northern Thailand above an altitude of $1000 \mathrm{~m}$ (Sri-Ngernyuang et al., 2003). This region is characterized by predictable rainy and dry seasons under the influence of Asian monsoons. There is generally a higher atmospheric evaporative demand and lower soil moisture during the 5- to 7-month dry season (e.g., Giambelluca et al., 1996; Tanaka et al., 2003). In such regions, ecohydrological processes are governed largely by the availability of soil water to trees (Nepstad et al., 1994; Jackson et al., 1999; O'Grady et al., 1999; Eamus et al., 2001; Saleska et al., 2003; Tanaka et al., 2004).

Our previous study revealed that the hill evergreen forest in the KogMa experimental watershed in northern Thailand transpires actively even in the late dry season. This was assessed with a numerical model and validated by observed data, such as the diurnal variations in latent heat fluxes measured with an eddy correlation technique, and the seasonal variations in sap flow measured in canopy trees (Tanaka et al., 2003). This phenomenon countered the expectation that evapotranspiration declines in the late dry season, as has been reported previously for an evergreen forest (Pinker et al., 1980) and other vegetation that is leafless during the dry season in Thailand (Aoki et al., 1998; Yoshifuji et al., 2001; Toda et al., 2002). However, limitation of transpiration under soil drought conditions in the late dry season has never been investigated at the individual tree scale, and the impact of soil drought on tree-water use is still unknown in the KogMa experimental watershed.

It has been reported that spatial patterns of soil water utilization in trees in subhumid or monsoonal regions appeared to be clearly due to spatial patterns of soil moisture, soil depth, and root development (Cermák et al., 1993; Meinzer et al., 1999; Tromp-van Meerveld and McDonnell, 2006). The hill evergreen forest at this site consists of various species and sizes (Bhumibhamon and Wasuwanich, 1970; Tangtham, 1974). Therefore, the decline in water use by individual trees caused by spatial differences in soil water utilization in trees may be more pronounced in some trees when the soil drought is more severe. Thus it is desirable that the ecohydrological processes at this site, investigating the impact of soil water stress due to the inter-annual dry sequence on transpiration be clarified based on individual tree-scale measurements.

This study aimed to reveal whether there is a limitation on transpiration by individual trees due to soil drought in the late dry season in the KogMa experimental watershed in northern Thailand, where transpiration peaks have appeared in the late dry season when there is higher atmospheric evaporative demand. To achieve this aim, we examined variations in both the sap flows and water potentials of evergreen trees following the seasonal transition from well-watered soil conditions to soil-drought conditions over a 2-year period. We measured sap flows and water potentials in four evergreen trees, two large and two small, with long-term measurements of hydro-meteorological elements. In addition, we confirmed the impact of soil drought on sap flow and water potential using a water supply treatment on an individual small tree in which symptoms of water stress were apparent.

\section{Materials and methods}

\subsection{Site}

This study was carried out in a sub-watershed of the KogMa experimental watershed, situated 1265-1420 m above mean sea level on Mount Pui $\left(18^{\circ} 48^{\prime} \mathrm{N}, 98^{\circ} 54^{\prime} \mathrm{E}\right)$ about $10 \mathrm{~km}$ west of Chiang Mai in northern Thailand. The mean annual temperature and rainfall for an 8-year period (1997-2004) were about $20{ }^{\circ} \mathrm{C}$ and $1700 \mathrm{~mm}$, respectively. The seasonal changes in both air temperature and rainfall show that this area has three seasons: a rainy season, an early (or cool) dry season and a late (or hot) dry season. The sub-watershed has an area of 8.63 ha covered with hill evergreen forest at a continuous canopy height of approximately 25-40 m (Tangtham, 1974). The dominant plant family is the Fagacea, including Lithocarpus, Quercus, and Castanopsis genera (Bhumibhamon and Wasuwanich, 1970). The leaf-area index is approximately $4.5 \mathrm{~m}^{2} \mathrm{~m}^{-2}$, with a small seasonal fluctuation (Tanaka et al., 2003; Takizawa et al., 2001). The soils consist of Reddish Brown Lateritic (Thailand classification) or Ustults (USDA Soil Taxonomy), with half sand content and a high porosity (60-74\%) (Tangtham, 1974; Hashimoto et al., 2004; Hashimoto, 2005). The plant available water, which was defined as the soil water contents between volumetric soil water contents $(\theta)$ measured at the matric potential of $-333 \mathrm{hPa}$ and the minimum $\theta$ during the entire measurement period in this study, was $0.11 \mathrm{~m}^{3} \mathrm{~m}^{-3}$ at the depth of $0.1 \mathrm{~m}$ in this site. The sub-watershed contains a $50-\mathrm{m}$ tall meteorological tower, which enabled us to reach the upper canopy layers. Two large evergreen trees and two saplings adjacent to the tower, of the dominant species at this site, were chosen for this study (Table 1).

\subsection{Water potentials and sap flow measurements}

Diurnal variations in leaf water potentials $\left(\Psi_{\text {leaf }}\right)$ were measured with a pressure chamber (PMS Instruments, Corvallis,

Table 1

Characteristics of sample trees selected for measurement of water potentials and sap flows

\begin{tabular}{|c|c|c|c|c|c|}
\hline & Family & Species & Height (m) & Stem diameter at breast height $(\mathrm{cm})$ & Crown projected area $\left(\mathrm{m}^{2}\right)$ \\
\hline CL & Lauraceae & Cinnamomum porrectum & 29.8 & 51.9 & 78.1 \\
\hline LL & Fagaceae & Lithocarpus elegans & 25.4 & 28.5 & 95.9 \\
\hline LS & Fagaceae & L. elegans & 4.8 & 4.0 & 6.7 \\
\hline CS & Lauraceae & C. porrectum & 1.4 & $1.3^{\mathrm{a}}$ & 0.4 \\
\hline
\end{tabular}

The data were measured in September 2003.

a Stem diameter at base. 
OR, USA). One to three sun-exposed leaves in the upper crown of each tree were sampled every three hours in the period from predawn to sunset. The stem-water potentials $\left(\Psi_{\text {stem }}\right)$ were substituted for by the measurements of $\Psi_{\text {leaf }}$ on the branches from the lowest crown of each tree, which were artificially prevented from transpiring by covering the branches with aluminum foil and plastic bags with well-wetted tissues one day prior to measuring; as, according to previous studies, the water status of the leaves that were prevented from transpiring can reasonably be taken equal to the water status of the stem around the base of the covered branches (Landsberg et al., 1976; Takizawa et al., 1996; David et al., 2004). Measurements were conducted on 4-5 November 2002 (early dry season), 2-3 March 2003 (late dry season), 2-3 September 2003 (rainy season), 16-17 November 2004 (early dry season), and 7-8 March 2004 (late dry season).

At the same time, sap-flow velocities were measured using a thermal heat-pulse method (Closs, 1958; Marshall, 1958) or a stem heat-balance method (Sakuratani, 1981; Baker and van Bavel, 1987), the selected method depending on the stem's diameter.

The thermal heat-pulse method was used on the trees with thick stems: the large Cinnamomum porrectum (CL), the large Lithocarpus elegans (LL), and the smaller L. elegans (LS) (Table 1). The instrumentation consisted of three sets of a heatpulse sensor (HP-1, Hayasi Denko Co., Tokyo, Japan) containing a heater probe and two thermistor probes $(2.0 \mathrm{~mm}$ in diameter, $50 \mathrm{~mm}$ in length). The heater probe was inserted radially into each tree stem at a height of $1.2 \mathrm{~m}$. The thermistor probes were inserted and aligned vertically $10 \mathrm{~mm}$ above and $7 \mathrm{~mm}$ below the heater probe. The three sensors were installed in holes drilled with a gauge guide into the outer xylem to a depth at which the sap-flow velocity peaked in the radial profiles. This location in the radial profiles of each tree was determined using two sets of sensors in both the rainy and the late dry seasons. One set was fixed while the position of the second was changed in $0.5 \mathrm{~cm}$ steps starting at the outer xylem and ending $5.0 \mathrm{~cm}$ toward the center. Measurements using the variable-depth sensor were conducted three or four times at each depth, at 20 min intervals. The distribution of sap-flow velocity along the radius was determined from the ratio of sap-flow velocity as measured with the variable-depth sensor to that measured with the fixed-depth sensor (Ueda and Shibata, 2002; Kuwada et al., 2002). A heat-pulse tracer was released for $1.5 \mathrm{~s}$ every $20 \mathrm{~min}$, and heat pulse velocities were stored on a data logger (CR10X, Campbell Scientific Inc., Longan, UT). To account for the influence of sap flow interruption around an implanted sensor, the heat-pulse velocity was adjusted to the sap-flow velocity using Swanson's method (Swanson and Whitfield, 1981; Kominami and Suzuki, 1993).

A stem heat-balance method was used in the tree with the thinnest stem, the smaller $C$. porrectum (CS) (Table 1). The gauge (SGA10, Dynamax Inc., TX, USA), which consists of a heating element, a thermopile and individual thermocouples, was attached to the $1.0-\mathrm{cm}$ diameter basal stem. The heating elements operated at a constant power, and the radial and longitudal heat fluxes were evaluated with the thermopile and thermocouples, respectively. The gauge and surrounding portions of stem were wrapped with foam insulation in addition to that supplied by the manufacturer, and the entire system was enclosed in a layer of aluminum foil in order to minimize spurious temperature gradients caused by the radiant heating of the stem. Data was collected every $5 \mathrm{~s}$, and the 20-min mean was stored on a data logger (CR23X, Campbell Scientific Inc.). The sheath conductance $\left(K_{\mathrm{sh}}\right)$ was determined from the values of sheath conductance calculated at predawn when transpiration seemed to be zero (Baker and van Bavel, 1987). The mass flows $\left(\mathrm{g} \mathrm{s}^{-1}\right.$ ) measured with this method were divided by the cross sectional area $\left(\mathrm{cm}^{2}\right)$ of the stem, and the mass flows corresponded to the sap-flow velocities $\left(\mathrm{cm} \mathrm{h}^{-1}\right)$ in this study. The stem heat-balance measurement was conducted for several days before and after the water potential measurements in September 2003, November 2003, and March 2004.

\subsection{Water supply treatment}

To confirm the impact of soil drought on water potential and sap flow in an individual tree, a water supply treatment was conducted in an individual tree that had noticeable symptoms of water stress. Hereby, since CS had noticeable symptoms, we supplied 1001 of water at a time $\left(=\sim 0.64 \mathrm{~m}^{2}\right)$ around CS on seven different occasions during the period 9-12 March 2004, to create well-watered soil conditions. To examine the recovery of water potential and sap flow in CS, sap-flow velocities (SGA10, Dynamax Inc.) and volumetric soil water content (CS615, Campbell Scientific Inc., Logan, UT, USA) at a depth of $20 \mathrm{~cm}, 30 \mathrm{~cm}$ west of CS were measured continuously from 9 to 13 March 2004. Diurnal variations in $\Psi_{\text {leaf }}$ and $\Psi_{\text {stem }}$ were measured on 9 March and 12-13 March.

\subsection{Soil moisture and meteorological measurements}

A 50-m tall meteorological tower and instruments for measuring meteorological factors over the canopy have been in place in the study area since February 1997 (Takizawa et al., 2001; Tanaka et al., 2003; Komatsu et al., 2003). Air temperature and relative humidity were measured at $43.4 \mathrm{~m}$ using a thermohygrograph (HMP45A, Vaisala Co., Helsinki, Finland). Downward short-wave radiation (MS402, Eko Instruments Co., Tokyo, Japan) was been measured at $50.5 \mathrm{~m}$. Volumetric water content $(\theta)$ and matric potential were measured at depths of $0.1-0.5 \mathrm{~m}$ below the forest floor near the tower using a time-domain reflectory sensor (CS-615, Campbell Scientific Inc., Logan, UT, USA) and a tensiometer (DIK3150, Daiki, Tokyo, Japan), respectively. Data were collected every $5 \mathrm{~s}$, and the 10-min means recorded in a data logger (CR23X, Campbell Scientific Inc.). Rainfall was measured using a tipping-bucket rain gauge $(20 \mathrm{~cm}$ diameter and $0.5 \mathrm{~mm}$ tip resolution; Ohta Keiki Co., Tokyo, Japan) and a storage-type rain gauge (hand made) in an open space.

\subsection{Method of analysis}

In this study, sap-flow velocities were used as an index of tree transpiration. Because sapwood conductive depth could not be 
identified in individuals (i.e. sap flow in CL and LL occurred even at a depth of $5.0 \mathrm{~cm}$ in the radial profiles), we could not estimate whole tree water use in individuals. Furthermore, this site is not supplied with electricity; thus, continuous measurements with multi-sensors could not be conducted. However sap-flow velocities measured with a single heat-pulse sensor have been found in previous studies to have a linear relationship with whole tree water use (Kominami and Suzuki, 1993; Ueda and Shibata, 2002; Kuwada et al., 2002; Giorio and Giorio, 2003; Iida et al., 2003; Hirose et al., 2005). Moreover, sap flows measured around the depth that sap-flow velocities peaked in the radial profiles are thought to contribute most to total sap flow. Therefore, it can be thought that seasonal changes in tree water use in each individual tree can be examined by using sap-flow velocities with a single sensor, if the sensor would be installed to the depth at which the sap-flow velocities peaked in the radial profiles.

Since heat-pulse velocity values sometimes decrease gradually during long-term, continuous measurements (Yoshifuji et al., 2001), we examined the time-series of data within approximately 6 months, during which period little decline appeared in the heat-pulse velocity values due to the continuous measurement. In this study, changes in both sap flow and water potential following the seasonal transitions were examined in two periods: November 2002 to March 2003 (Period A), and September 2003 to the beginning of March 2004 (Period B).

To examine the impact of soil drought on sap-flow velocity in the late dry season for two periods, we defined the reduction in sap-flow velocity as follows:

Reduction $=1-\frac{f_{\text {late }}(\mathrm{VPD})}{f_{\text {early }}(\mathrm{VPD})}$

where $f_{\text {late }}(\mathrm{VPD})$ is the fitted curve of daytime mean sap-flow velocity $\left(J_{\mathrm{s}}\right)$ versus daytime mean VPD in the late dry season using a non-rectangular hyperbola (e.g., Prioul and Chartier, 1977 ), and $f_{\text {early }}(\mathrm{VPD})$ is the fitted curve of $J_{\mathrm{s}}$ versus daytime mean VPD in the early dry season using a non-rectangular hyperbola (see Figs. 5 and 6). According to Pataki et al. (2000), reduction in $J_{\mathrm{s}}$ represents a decline in water use due to soil moisture decline at a given atmospheric evaporative demand in an individual tree, when the two comparative seasons can be differentiated clearly by soil water conditions. The period chosen for analyzing the response to VPD was about 3 weeks around the water potential measurements in each season except for CS. Seasonal changes in the relationships between $J_{\mathrm{s}}$ and daytime mean VPD were tested with $F$-tests comparing a null model of $J_{\mathrm{s}}$ and daytime mean VPD with lumped data in both early and late dry seasons and an alternative model for each season. Statistical analyses were conducted with R-2.2.1 for Windows (R Development Core Team, 2005).

\section{Results}

\subsection{Rainfall and soil moisture}

Fig. 1 shows the inter-annual variations in rainfall at the KogMa watershed, rainfall measured near the KogMa

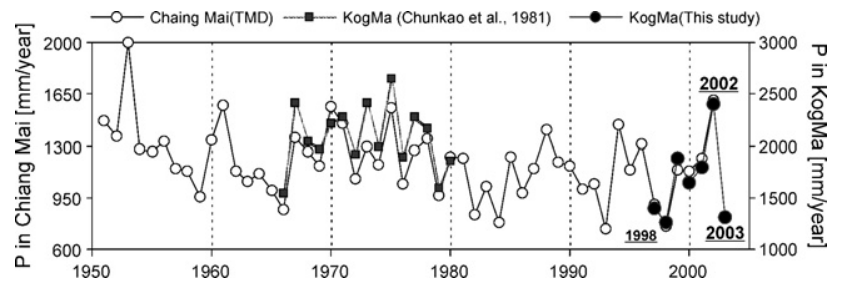

Fig. 1. Inter-annual variations in rainfall $(\mathrm{P})$ at the KogMa watershed, rainfall measured around KogMa watershed (Chunkao et al., 1981), and long-term rainfall records in Chaing Mai City. Black circles represent annual rainfalls measured at KogMa watershed in this study. Black squares represent annual rainfalls near KogMa watershed over a 15-year period (1966-1980) recorded by Chunkao et al. (1981). Open circles represent rainfall records monitored at the nearest meteorological observatory, the Thailand Meteorological Department (TMD) in Chaing Mai City. Note: just the TMD rainfall is represented using the left vertical axis.

watershed (Chunkao et al., 1981), and rainfall records monitored at the Thailand Meteorological Department (TMD), the nearest meteorological observatory, which is situated $312 \mathrm{~m}$ above mean sea level in Chaing Mai City $\left(18^{\circ} 47^{\prime} \mathrm{N}, 98^{\circ} 59^{\prime} \mathrm{E}\right)$. The inter-annual variation patterns of rainfall at and near the site corresponded to the rainfall pattern recorded by TMD, although the amount of annual rainfall at these three locations was lowest at TMD, which corresponds with the observation that precipitation is lower at lower altitudes in northern Thailand (Dairaku et al., 2000; Kuraji et al., 2001). Thus, the annual rainfall at the site in 2002 was greater than in the previous 20 years, and the annual rainfall in 2003 was as low as that measured in 1997 and 1998 when unusually severe droughts occurred in Southeast Asia coinciding with the El Niño of 1997-1998 (Walsh and Newbery, 1999; Nakagawa et al., 2000; Wang and Weisberg, 2000).

In 2002, the rainy season began in May and rainfall was observed until the next January (Fig. 2). The volumetric soil water content drastically decreased starting January 2003 in Period A. On the other hand, since rainfall decreased in October 2003, the volumetric soil water content drastically decreased beginning in October 2003 in Period B. As shown in Fig. 2, the volumetric water contents in this site showed small variations under the dry conditions during late dry seasons (i.e. the matric potentials $<-800 \mathrm{hPa}$ ). Thus, the soil moisture measurements made here at depths of $0.1-0.5 \mathrm{~m}$ could not detect distinctive differences in the late dry season between 2003 (for Period A) and 2004 (for Period B) (Fig. 2). However, the sliding 120-day total rainfall in the late dry season in 2004 was much lower than that of the late dry season in 2003.

\subsection{Sap-flow velocities, $\Psi_{\text {leaf }}$, and $\Psi_{\text {stem }}$}

In Period A, the diurnal peaks of the sap-flow velocities from three of the trees in the late dry season were larger or very similar to the peaks from the early dry season (Fig. 3b and c). In Period B, the diurnal peaks of the sap-flow velocities in CL, LL, and LS during the late dry season also were larger or very similar to the peaks from the rainy and early dry seasons. The sap-flow velocity peaks in CS during the late dry season were very similar to those from the early dry season. Leaf fall in CS 

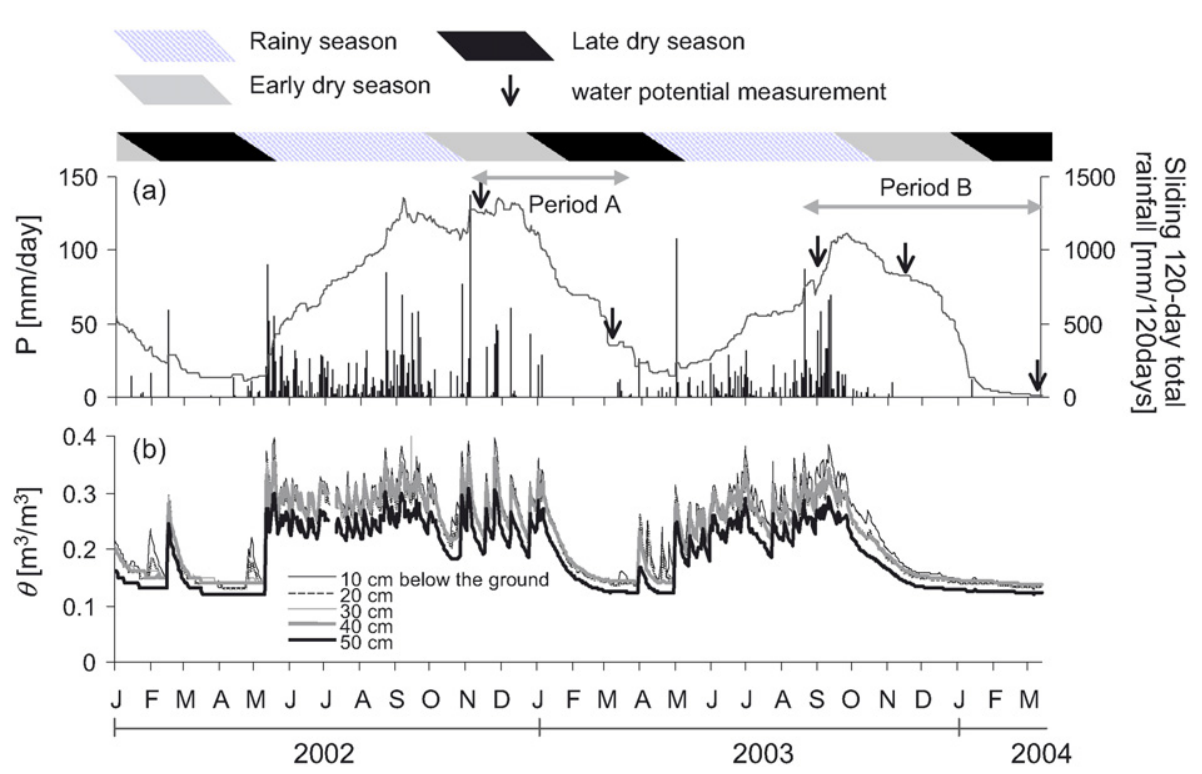

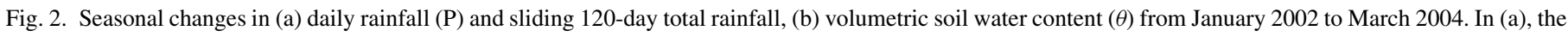
black bar and black line represent the daily rainfall and sliding 120-day total rainfall, respectively.

obviously occurred in the early dry season in 2003, and the difference in these peaks in CS between the rainy season and early dry season was probably caused by this leaf fall.

The minimum $\Psi_{\text {leaf }}$ at midday decreased in LL, LS, and CS with the seasonal transition from wet soil conditions to the late dry season in both Periods A and B, whereas, there was no obvious seasonal change in the minimum midday $\Psi_{\text {leaf }}$ in CL, which ranged between -1.9 and $-2.2 \mathrm{MPa}$ (Fig. 3d). In Period A, the predawn $\Psi_{\text {stem }}\left(\Psi_{\text {pre }}\right)$ in the four trees slightly decreased following the seasonal transition from wet soil to the late dry season (Fig. 3e). In Period B, the $\Psi_{\text {pre }}$ in CL, LL, and LS also decreased slightly following the seasonal transition from the rainy season to the late dry season, whereas, the $\Psi_{\text {pre }}$ in CS decreased significantly to $-1.1 \mathrm{MPa}$ during this same period. The $\Psi_{\text {pre }}$ from CS in the late dry season in Period B was the lowest of any of our individuals during the 2-year period.

\subsection{The recovery of sap-flow velocity, water potential in CS after water supply treatment}

The significant decrease in $\Psi_{\text {pre }}$ from CS suggested that CS had suffered from water stress due to soil drought during the late dry season in Period B. To confirm whether CS had suffered from water stress due to soil drought, we started to supply water to CS on 9 March 2004. After seven water supply treatments, the $\Psi_{\text {pre }}$ increased from $-1.1 \mathrm{MPa}$ on 8 March to $-0.14 \mathrm{MPa}$ on 13 March. The minimum $\Psi_{\text {stem }}$ at midday also increased from $-1.34 \mathrm{MPa}$ on 8 March to $-0.38 \mathrm{MPa}$ on $13 \mathrm{March}$, although the minimum $\Psi_{\text {leaf }}$ at midday was almost constant at around $-1.5 \mathrm{MPa}$ before and after water supply treatments (Fig. 4d). The diurnal peaks in sap-flow velocity in CS increased gradually from 9 to 13 March, while the diurnal peaks in sapflow velocity in CL without water supply treatments were almost constant in the same period (Fig. $4 \mathrm{~b}$ and c). We confirmed that the tendency found in CL could be found in the diurnal variations in sap-flow velocities in LL, and LS. However, it is still unknown whether the increase in sap-flow velocity had been caused by the increase in soil water status around CS, since the vapor pressure deficit (VPD) also increased gradually from 9 to 13 March (Fig. 4a).

To confirm the impact of water supply treatment on sap-flow velocities in CS, daytime mean sap-flow velocity $\left(J_{\mathrm{s}}\right)$ was related to the daytime mean VPD in CS (Fig. 5), and the $J_{\mathrm{s}}$ from 9 to 10 March 2004 were plotted around the non-rectangular hyperbola that was fitted to $J_{\mathrm{s}}$ versus daytime mean VPD in the late dry season before the water supply treatment. After that, $J_{\mathrm{s}}$ increased in spite of an almost constant VPD until 12 March, and the increase in $J_{\mathrm{s}}$ stopped on 13 March. We confirmed that the same tendencies shown in Fig. 5 could be found in the relationship between $J_{\mathrm{s}}$ and potential evaporations that were calculated using the Penman-Monteith equation (Monteith and Unsworth, 1990). Therefore, it is thought that the impact of soil drought on CS was removed by water supplementation and that $J_{\mathrm{s}}$ on 12-13 March was close to what $J_{\mathrm{s}}$ would have been with daytime mean VPD $\geq 15 \mathrm{hPa}$ in the early dry season. These recoveries of sap-flow velocities and water potentials in CS after water supplementation confirmed that the reductions in sap-flow velocity and $\Psi_{\text {pre }}$ were caused by stomatal closure due to soil drought (e.g., Davies and Zhang, 1991; Meinzer et al., 1995).

\subsection{Reduction in sap-flow velocities in the late dry season}

While the daytime mean sap-flow velocities $\left(J_{\mathrm{S}}\right)$ in CL, LL and LS were related to the daytime mean VPD in each season during both Periods $\mathrm{A}$ and $\mathrm{B}$, the measurements tended to plateau when the mean VPD exceeded about $15 \mathrm{hPa}$ (Fig. 6). This plateau pattern was observed distinctively in the late dry season, because the high daytime mean VPD $\geq 15 \mathrm{hPa}$ was frequently observed in the late dry season and rarely observed 

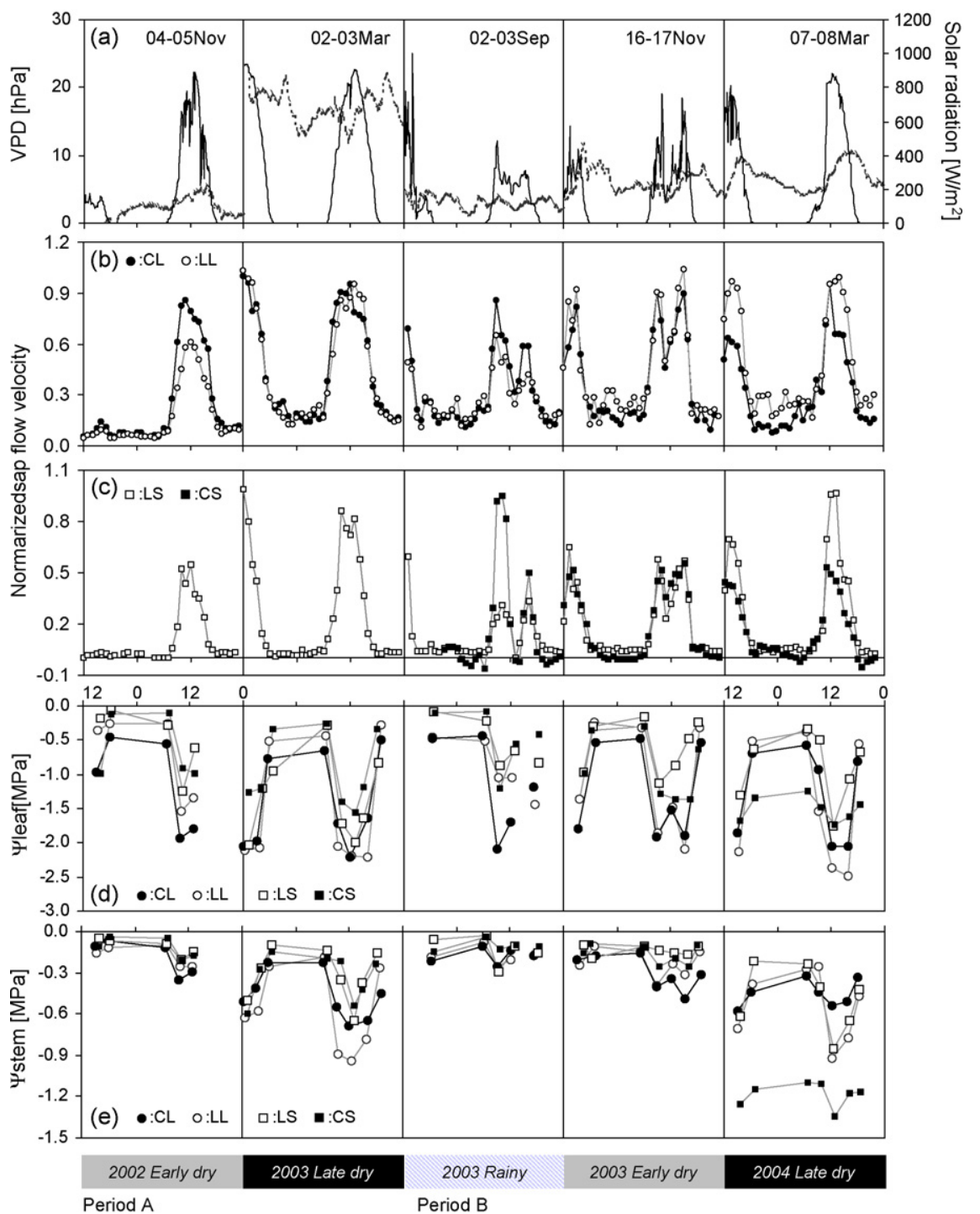

Fig. 3. Diurnal and seasonal variations in (a) solar radiation (solid line) and vapor pressure deficit (VPD) (dotted line), (b) normalized sap-flow velocities in CL (black circle) and LL (open circle), (c) normalized sap-flow velocities in LS (open square) and CS (black square), (d) leaf water potentials ( $\left.\Psi_{\text {leaf }}\right)$, and (e) stem-water potentials $\left(\Psi_{\text {stem }}\right)$ in four individuals. Sap-flow velocities in the period between November 2002 and March 2003 (Period A) were normalized by the maximum value in Period A in each tree. Sap-flow velocities in the period between September 2003 and March 2004 (Period B) were normalized by the maximum values in Period B in each tree.

in the rainy or the early dry seasons (Figs. 3, 5 and 6); this plateau pattern indicates that stomatal closure occurred due to high VPD in the late dry season of both Periods A and B (e.g., Hogg and Hurdle, 1997).

In Period A, the relationships between $J_{\mathrm{s}}$ and the daytime mean VPD in CL, LL and LS during the late dry season were very similar to those in the early dry season (Fig. 6, left column). On the other hand, differences in the relationships between $J_{\mathrm{s}}$ and daytime mean VPD in these three trees became more apparent during Period B than Period A, and $J_{\mathrm{s}}$ from the rainy season were plotted around the fitted curves in the early dry season (Fig. 6, right column). We confirmed that the same tendencies shown in Fig. 6 could be found in the relationship between $J_{\mathrm{s}}$ and potential evaporations that were calculated using the Penman-Monteith equation (Monteith and Unsworth, 1990).
As the data for each season in Fig. 6 was differentiated clearly by soil water content, the impact of soil drought on $J_{\mathrm{s}}$ could be examined by using the reduction in $J_{\mathrm{s}}$ (Eq. (1)). This study examined $J_{\mathrm{s}}$ under conditions when VPD was at a daytime mean of $\leq 15 \mathrm{hPa}$ (Fig. 7). During Period A, the reduction in $J_{\mathrm{s}}$ in individual trees mostly ranged from 0 to $20 \%$ (Fig. 7 a). On the other hand, the reduction in $J_{\mathrm{s}}$ during Period B ranged from 10 to $40 \%$ (Fig. 7b). This means that $J_{\mathrm{S}}$ in CL, LL, and LS also decreased at a given VPD in the late dry season of Period B due to soil drought, although it was still unknown, whether leaf loss due to soil drought (e.g., Borchert, 1994) or stomatal closure due to soil drought (e.g., Davies and Zhang, 1991; Meinzer et al., 1995) caused the reduction in $J_{\mathrm{s}}$. Moreover, the degree of reduction in $J_{\mathrm{s}}$ was different among tree sizes: $J_{\mathrm{s}}$ decreased more in the smaller trees than the larger trees in Periods A and B, with the greatest reduction in $J_{\mathrm{s}}$ occurring in CS during Period B. 

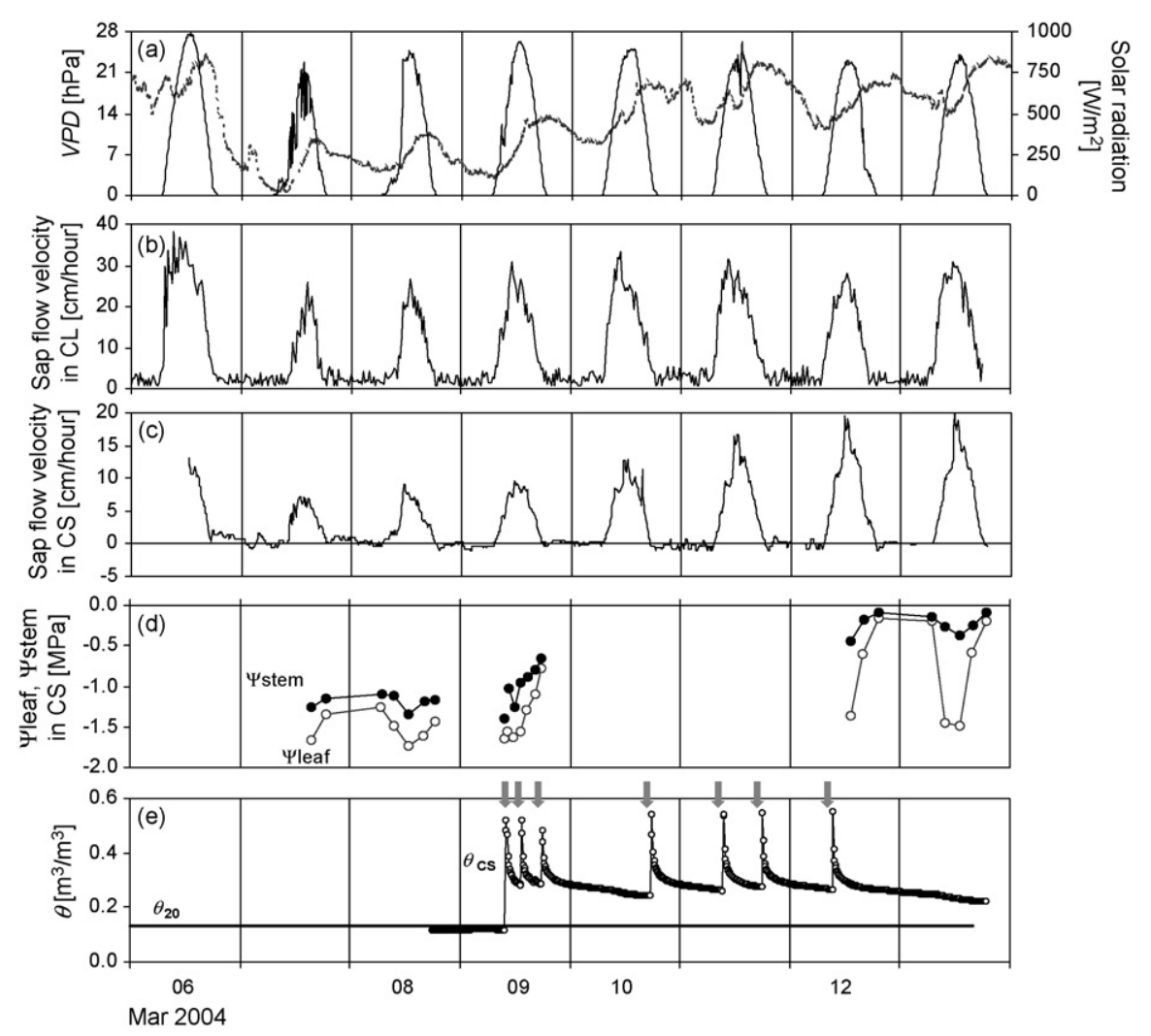

Fig. 4. Recovery of sap flow and water potential in CS after water supply treatment. Diurnal variations in (a) solar radiation (solid line) and vapor pressure deficit (dotted line), (b) sap-flow velocities in CL without irrigation, (c) sap-flow velocities in CS, (d) $\Psi_{\text {leaf }}$ (open circle) and $\Psi_{\text {stem }}$ (black circle) in CS, and (e) soil water contents measured at $20 \mathrm{~cm}$ below the ground near the tower $\left(\theta_{20}\right)$ and around CS at a depth of $20 \mathrm{~cm}\left(\theta_{\mathrm{CS}}\right)$. Vertical arrows represent the times at which water supply treatments were conducted.

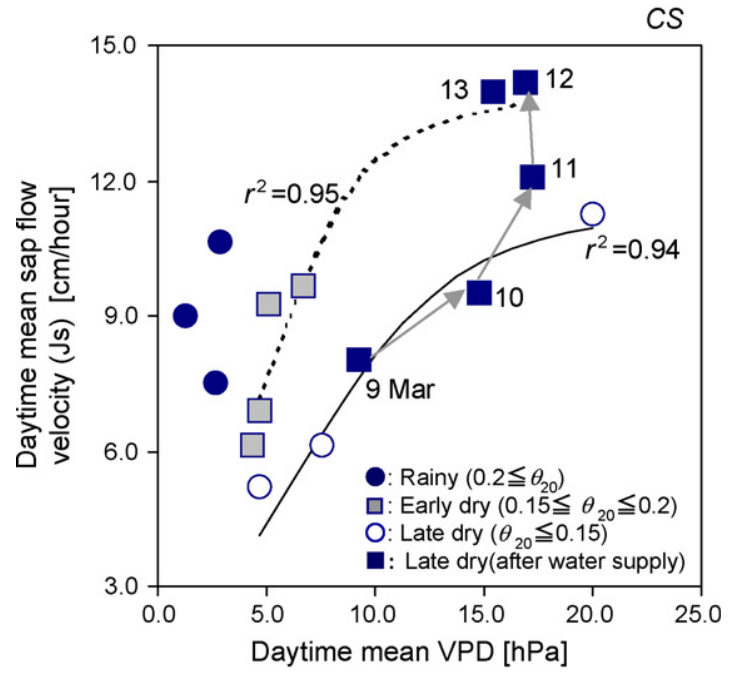

Fig. 5. Daytime mean sap-flow velocity $\left(J_{\mathrm{s}}\right)$ in relation to daytime mean vapor pressure deficit (VPD) in CS. Three seasons are differentiated: black circles, gray squares, and open circles represent the rainy season, the early dry season, and the late dry season, respectively. Symbols are also categorized using volumetric soil water content, measured at $20 \mathrm{~cm}$ below the ground $\left(\theta_{20}\right)$, while the black squares represent $J_{\mathrm{s}}$ after water supply treatment in the late dry season. A non-rectangular hyperbola in the late dry season (solid line) was fitted to $J_{\mathrm{s}}$ vs. VPD using $J_{\mathrm{s}}$ before water supplementation $(P<0.05)$. The nonrectangular hyperbola in the early dry season (dotted line) was fitted using $J_{\mathrm{s}}$ measured in the early dry season and on $12-13$ March $2004(P>0.05)$.

\section{Discussion}

The amount of rainfall preceding the late dry season of 2004 was significantly less than that preceding the late dry season in 2003 (Fig. 2), and the distinctive reduction in $J_{\mathrm{s}}$ in individual trees was not found in the late dry season of 2003 (Fig. 7). On the other hand, the reduction in $J_{\mathrm{s}}$ in individual trees became more apparent in the late dry season of 2004, with the most significant reduction in $J_{\mathrm{s}}$ and $\Psi_{\text {pre }}$ being found in the smallest tree (Figs. 3 and 7). The recovery of sap-flow velocity and water potential in the smallest tree after water supplementation confirmed that the reductions in sap-flow velocity and predawn stem-water potential in the smallest tree were caused by soil drought.

A high demand for water in trees and a deep rootable soil can lead to the development of deep and extensive root systems (Cermák et al., 1993; Meinzer et al., 1999; Tromp-van Meerveld and McDonnell, 2006). Canadell et al. (1996) showed that a tropical evergreen tree is likely to have a deep rooting depth with the maximum ranging from 2.0 to $18.0 \mathrm{~m}$ (the average was $7.3 \pm 2.8 \mathrm{~m}$ ). Moreover, a greater root biomass has been estimated in evergreen forests than deciduous forests or savanna forests in Thailand (Ogawa et al., 1965; Kira et al., 1967). Such a deep root system seems to develop over decades or centuries. The roots in a sapling like CS would most 


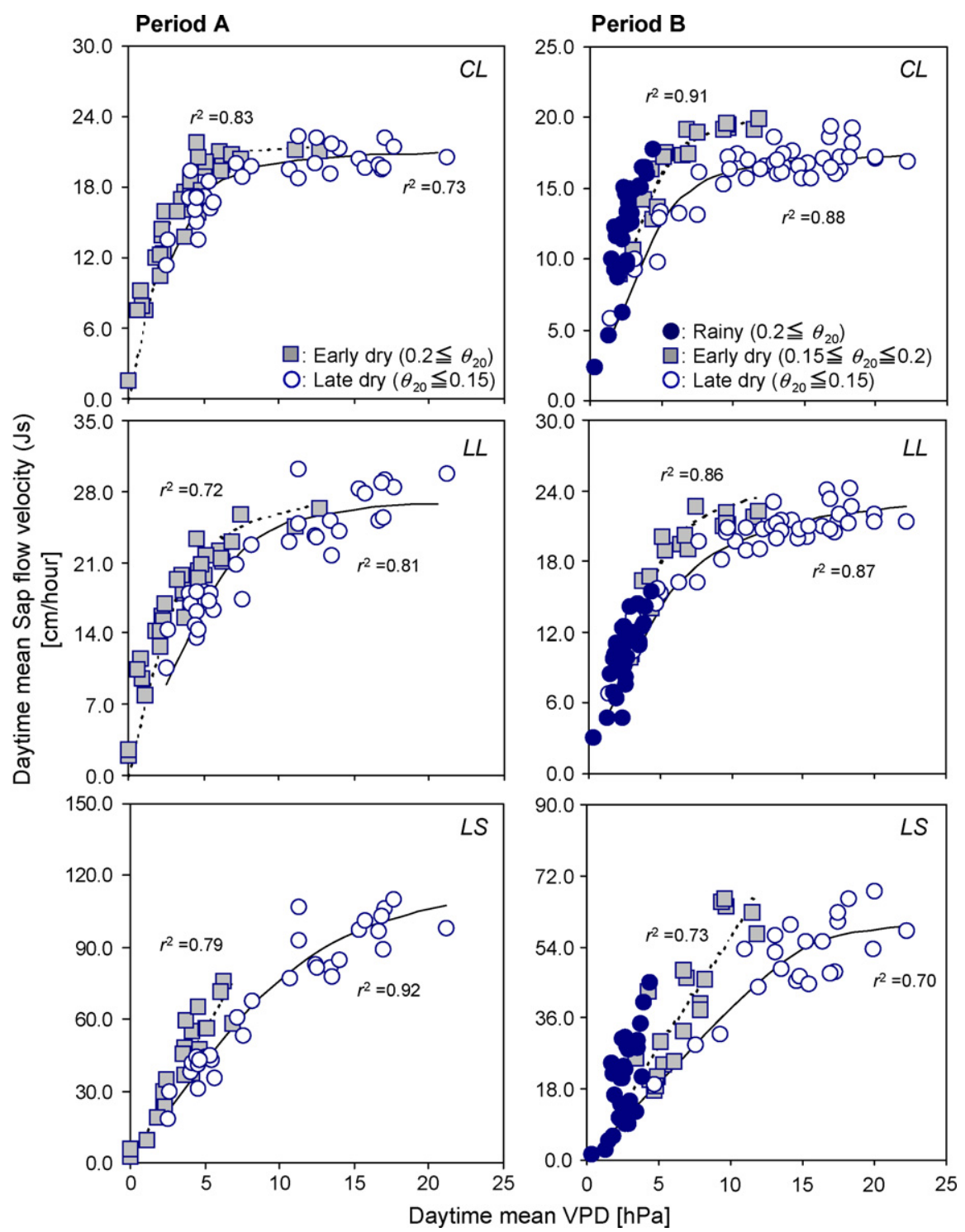

Fig. 6. Daytime mean sap-flow velocity $\left(J_{\mathrm{s}}\right)$ in relation to daytime mean vapor pressure deficit (VPD) in CL, LL, and LS in Period A (left column) and Period B (right column). The symbols are the same as in Fig. 5. On the left, the response to $J_{\mathrm{s}}$ vs. VPD in the early dry season (dotted line) and the late dry season (solid line) was fitted using the non-rectangular hyperbola $(P>0.05)$. On the right, the response to $J_{\mathrm{s}}$ vs. VPD in the early season (dotted line) and the late dry season (solid line) was again fitted using the non-rectangular hyperbola $(P<0.05$ for all individuals except LL and LS in the early dry season).

likely not have had such a depth. Usually, the shallower portions of soil are drier than the deeper portions during no-rain periods (e.g., Hodnett et al., 1995; Cook et al., 1998). The dry soil in the shallower soil layer could lead to a more significant decrease in water use in saplings than in larger trees during the late dry season, in particular, under an unusually prolonged dry season such as that we recorded in the late dry season of 2004 at this site. The lowest $\Psi_{\text {pre }}$ in CS in the late dry season of 2004 $(-1.1 \mathrm{MPa})$ supports evidence that severely dry soil appeared in a shallower soil layer (Fig. 3). Further, $\Psi_{\text {pre }}$ can be substituted for the soil water potential in contact with the roots when transpiration and sap flows do not occur (Hinckley et al., 1978; Richter, 1997; Bucci et al., 2004).

At this site, the stream flow has been never interrupted, even in the late dry season (Yamada et al., 2001; Tanaka et al., 2003), indicating that there may be sufficient soil water below ground to maintain transpiration over the late dry season, although soil water status at depths exceeding $0.5 \mathrm{~m}$ has not been investigated. A numerical analysis using a Soil-Plant-Atmosphere-Continuum model shows that a rooting depth of over 4$5 \mathrm{~m}$ is needed to maintain transpiration in the late dry season under unsaturated soil conditions (Tanaka et al., 2004). The possibility of trees establishing such a deep root system at this site was supported by a penetration test, which showed that the soil became harder at a depth of 4-5 $\mathrm{m}$ around the tower (i.e., rootable depth corresponds to 4-5 m) (Tanaka et al., 2004). The sap flows observed in the top of the watershed ridge, where the penetration test showed a greater rootable depth than at the tower site and where the groundwater table (i.e., saturated soil water) might appear at a greater depth, also showed active transpiration in the late dry season $(\mathrm{N}$. Yoshifuji, personal communication). A previous study conducted on the Malaysian 


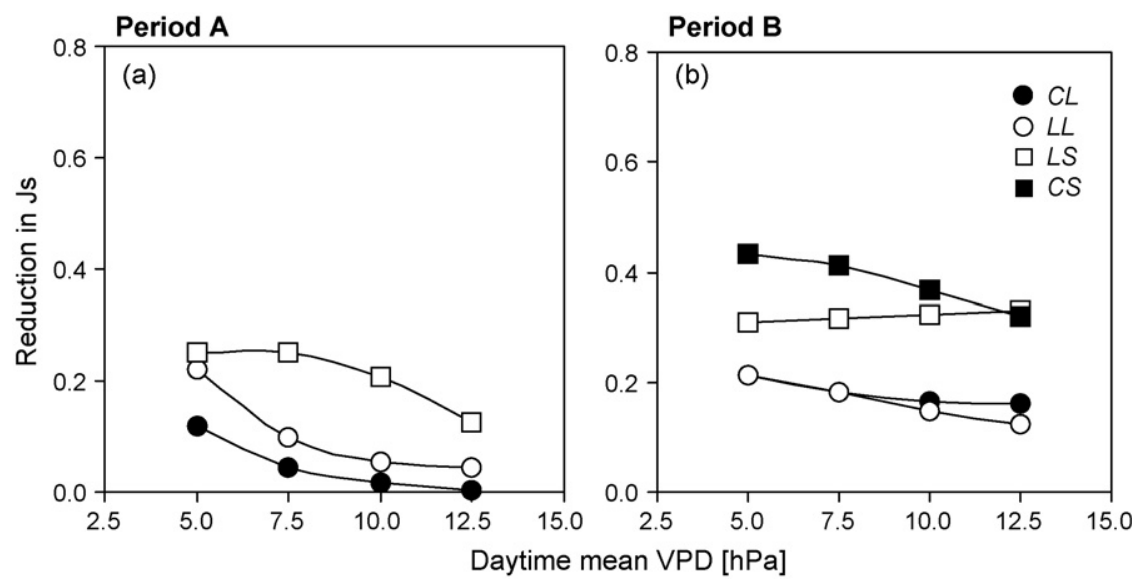

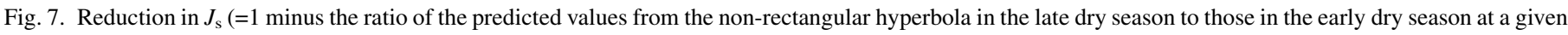

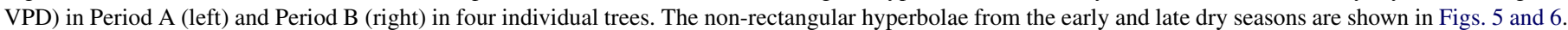

Peninsular (Burnham, 1989) showed a great rootable depth $>5 \mathrm{~m}$ in granites, which supports the existence of such a great rootable soil depth in the granites at this site. This suggests that there is unsaturated water or saturated water stored in a deep soil layer, and that developed roots in larger trees like CL, LL, and also LS can reach this depth to maintain transpiration in the late dry season in this evergreen forest. Thus, it seems likely that water use in larger trees is less limited by dry soil in shallower soil layers than that in saplings, and that canopy-scale transpiration at this site could be actively maintained even in the late dry season since transpiration from larger trees is thought to contribute most of the total transpiration (e.g., Roberts et al., 1993, 2005), owing to intense solar radiation and VPD to which the upper canopy is exposed, and the high leafarea index of the upper canopy.

Furthermore, saplings are generally shaded by canopy trees from the more intense solar radiation and VPD in the late dry season, and the shade might enable saplings to survive even an unusually prolonged dry season, although severe soil drought has a strong impact on water use in saplings (Figs. 4, 5 and 7b). The quick recovery of sap flows and water potentials suggests that the sapling in this study did not suffer from fatal leaf desiccation or dysfunction (i.e., xylem cavitations) in the late dry season (Figs. 4 and 5), and supports the possibility that saplings can survive even an unusually prolonged dry season. If intensive selective cutting of emergent trees for timber was to be conducted in this forest, saplings would be exposed to higher atmospheric evaporative demand and would also suffer from more severe soil drought because of an increase in forest-floor evaporation in a prolonged dry season such as the late dry season of 2004. This might cause fatal leaf desiccation or dysfunction in saplings. This study thus suggests that intensive selective cutting of emergent trees in a hill evergreen forest could lead to fatal water stress in saplings with shallower roots, and might possibly cause an irreversible change in forest structure and species composition.

In this study, it is difficult to judge whether the results are really representative of the forest as a whole because of the small sample size due to the lack of facilities. The physiological and geophysical measurements here, which did not include sap flows and water potentials in response to the horizontal variability of soil water conditions and the soil water conditions below $0.5 \mathrm{~m}$ depth, were indicative rather than final. Even so, we believe this study reveals new information because it is based on individual tree-scale observations encompassing a range of sizes, and it supports our earlier study based on a numerical simulation, eddy covariance techniques, and watershed water balance that active canopy-scale transpiration in the late dry season is maintained with soil water stored in a thick soil layer and developed root systems in an hill evergreen forest (Tanaka et al., 2003, 2004). This study also postulated that intensive selective cutting of emergent trees in a hill evergreen forest could cause irreversible changes because saplings can suffer from severe water stress in unusually prolonged dry seasons.

\section{Conclusions}

This study was undertaken to show whether transpiration by individual trees is limited due to soil drought in the late dry season in a hill evergreen forest in northern Thailand where canopy-scale transpiration peaks appear in the late dry season. To do this, we examined changes in sap-flow velocities and water potentials from wet soil conditions to soil drought conditions in four evergreen trees over a span of 2 years.

The amount of rainfall preceding the late dry season of 2004 was significantly smaller than the rainfall preceding the late dry season of 2003. Although the decrease in sap-flow velocities due to soil drought were not apparent in individuals in the late dry season of 2003, the reduction in sap-flow velocities due to soil drought in the four trees became more apparent, ranging between 10 and $40 \%$ at a given VPD in the late dry season of 2004. Moreover, the reductions in sap-flow velocity and predawn stem-water potential were most significant in the smallest tree. The recovery of sap-flow velocity and water potential in the smallest tree after water supplementation confirmed that the reductions in sap-flow velocity and predawn stem-water potential in the smallest tree were caused by soil drought. 
These results suggest that shallower roots in smaller trees could be the reason for the significant decreases in water use in the smallest tree. While, deep roots in a larger tree could be the reason for the lower impact of soil drought on water use in a larger tree. In conclusion, this study based on physiological measurements in individual trees encompassing a range of sizes' supports our previous study based on numerical simulation that active canopy-scale transpiration in the late dry season could be maintained by deep soil water and developed root systems. Further geophysical measurements of rootable soil depth and deep soil water in this watershed and physiological measurements of water use, photosynthesis, growth, and also the rooting depth in individual trees encompassing a range of sizes and species during a severe soil drought coinciding with ENSO would provide a broader understanding of the ecohydrological processes in a hill evergreen forest in northern Thailand under Asian monsoon influences, and also provide new insights for management of hill evergreen forests.

\section{Acknowledgements}

This study was supported by the CREST program of JST (Japan Science and Technology Agency). We are grateful to Dr. Katumi Musiake of Fukushima University, Dr. Taikan Oki of the University of Tokyo, Dr. Nipon Tangtham of the Kasetsurt University, and other GAME Tropics members for providing the opportunity to conduct this study. Some measurements were supported by Ms. Mika Kawamoto of Kasetsurt University, Dr. Izumi Kosaka of Japan Conservation Engineers, Dr. Shoji Hashimoto of the Forestry and Forest Products Research Institute, and Dr. Mikio Satomura of the Shizuoka University. Fruitful discussions with Mr. Norifumi Hotta of the University of Tokyo, Dr. Hikaru Komatsu of the Kyushu University are also greatly appreciated.

\section{References}

Aoki, M., et al., 1998. Evaluation of surface fluxes over a paddy field in a tropical environment: some findings from a preliminary observation of GAME. J. Jpn. Soc. Hydrol. Water Resour. 11, 39-60.

Baker, J.M., van Bavel, C.H.M., 1987. Measurement of mass flow of water in the stems of herbaceous plants. Plant Cell Environ. 10, 777-782.

Bhumibhamon, S., Wasuwanich, P., 1970. The structural characteristics of Huay Kog-Ma forest (in Thai with English summary). Kog-Ma watershed Res. Bull. 20 pp. Dept. of Conserv., Fac. of For., Kasetsart Univ., Bangkok.

Borchert, R., 1994. Soil and stem water storage determine phenology and distribution of tropical dry forest trees. Ecology 75, 1437-1449.

Bruijnzeel, L.A., 2004. Hydrological functions of tropical forests: not seeing the soil for the trees. Agric. Ecosyst. Environ. 104, 185-228.

Bucci, S.J., Scholz, F., Goldstein, G., Meinzer, F.C., Hinojosa, J.A., Hoffmann, W.A., Franco, A.C., 2004. Processes preventing nocturnal equilibration between leaf and soil water potential in tropical savanna woody species. Tree Physiol. 24, 1119-1127.

Burnham, C.P., 1989. Pedological processes and nutrient supply from parent material in tropical soils. In: Proctor, J. (Ed.), Mineral Nutrients in Tropical Forest and Savanna Ecosystems. Blackwell, Oxford, pp. 27-41.

Canadell, J., Jackson, R.B., Ehleringer, J.R., Mooney, H.A., Sala, O.E., Schulze, E.-D., 1996. Maximum rooting depth for vegetation types at the global scale. Oecologia 108, 583-595.
Cermák, J., Matyssek, R., Kucera, J., 1993. Rapid response of large, droughtstressed beech trees to irrigation. Tree Physiol. 12, 281-290.

Chunkao, K., Tangtham, N., Boonyawat, S., Niyom, W., 1981. Watershed management research on mountainous land (in Thai with English abstract), 15-year tentative report, 1966-1980, p. 62. Dept. of Conserv., Fac. of For., Kasetsart Univ., Bangkok.

Closs, R.H., 1958. The heat pulse method for measuring rate of sap flow in a plant stem. N. Z. J. Sci. 1, 281-288.

Cook, P.G., Hatton, T.J., Pidsley, D., Herczeg, A.L., Held, A., O'Grady, A.P., Eamus, D., 1998. Water balance of tropical woodland ecosystem, Northern Australia: a combination of micro-meteorological, soil physical and groundwater chemical approaches. J. Hydrol. 210, 161-177.

Dairaku, K., Kuraji, K., Suzuki, M., Thangtam, N., Jirasuktaveekul, W., Punyatrong, K., 2000. The effect of rainfall duration and intensity on orographic rainfall enhancement in a mountainous area: a case study in the Mae Chaem watershed, Thailand. J. Jpn. Soc. Hydrol. Water Resour. 13, $57-68$.

David, T.S., Ferreira, M.I., Cohen, S., Pereira, J.S., David, J.S., 2004. Constraints on transpiration from an evergreen oak tree in southern Portugal. Agric. For. Meteol. 122, 193-205.

Davies, W.J., Zhang, J., 1991. Root signals and the regulation of growth and development of plants in drying soil. Ann. Rev. Physiol. Plant Mol. Biol. 42, 55-76.

Eamus, D., Hutley, L., O’Grady, A.P., 2001. Carbon and water fluxes above a north Australian savanna. Tree Physiol. 21, 977-988.

Giambelluca, T.W., Tran, L.T., Ziegler, A.D., Menard, T.P., Nullet, M.A., 1996. Soil-vegetation-atmosphere processes: simulation and field measurement for deforested sites in northern Thailand. J. Geophys. Res. 101, 2586725885.

Giorio, P., Giorio, G., 2003. Sap flow of several olive trees estimated with the heat-pulse technique by continuous monitoring of a single gauge. Environ. Exp. Bot. 49, 9-20.

Hashimoto, S., Tanaka, N., Suzuki, M., Inoue, A., Takizawa, H., Kosaka, I., Tanaka, K., Tantasirin, C., Tangtham, N., 2004. Soil respiration and soil $\mathrm{CO}_{2}$ concentration in a tropical forest, Thailand. J. For. Res. 9, 75-79.

Hashimoto, S., 2005. Temperature sensitivity of soil $\mathrm{CO}_{2}$ production in a tropical hill evergreen forest in northern Thailand. J. For. Res. 10, 497-503.

Hinckley, T.M., Aslin, R.G., Aubuchon, R.R., Metcalf, C.L., Roberts, J.E., 1978. Leaf conductance and photosynthesis in four species of the oakhickory forest type. For. Sci. 24, 73-84.

Hirch, P., 1987. Deforestation and development in Thailand. Singapore J. Trop. Geogr. 8, 129-138.

Hirose, S., Kume, A., Takeuchi, S., Utsumi, Y., Otsuki, K., Ogawa, S., 2005. Stem water transport of Lithocarpus edulis, an evergreen oak with radialporous wood. Tree Physiol. 25, 221-228.

Hodnett, M.G., Pimentel da Silva, L., da Rocha, H.R., Cruz Senna, R., 1995. Seasonal soil water storage changes beneath central Amazonian rainforest and pasture. J. Hydrol. 170, 233-254.

Hogg, E.H., Hurdle, P.A., 1997. Sap flow in trembling aspen: implications for stomatal responses to vapor pressure deficit. Tree Physiol. 17, 501-509.

Iida, S., Kobayashi, Y., Tanaka, T., 2003. Continuous and long-term measurement of sap flux using Granier method. J. Jpn. Soc. Hydrol. Water Resour. 16, 13-22 (in Japanese, with English summary).

Jackson, R., Moore, L.A., Hoffmann, W.A., Pockman, W.T., Linder, C.R., 1999. Ecosystem rooting depth determined with caves and DNA. Proc. Natl. Acad. Sci. U.S.A. 96, 11387-11392.

Kanae, S., Oki, T., Mushiake, K., 2001. Impact of deforestation on regional precipitation over the Indochina Peninsula. J. Hydromet. 2, 51-70.

Kira, T., Ogawa, H., Yoda, K., Ogino, K., 1967. Comparative ecological studies on three main types of forest vegetation in Thailand. 4 Dry matter production. Nat. Life S.E. Asia 5, 149-174.

Komatsu, H., Yoshida, N., Takizawa, H., Kosaka, I., Tantasirin, C., Suzuki, M., 2003. Seasonal trend in the occurrence of nocturnal drainage flow on a forested slope under a tropical monsoon climate. Boundary Layer Metorol. 106, 573-592.

Kominami, Y., Suzuki, M., 1993. Comparison of transpiration rate measured by heat pulse method and water uptake rate in single trees of Chamaecyparis 
obtusa and Pinus densiflora. IAHS Publ. Exchange Proc. Land Surface Range Space Time Scales 212, 27-34.

Kuraji, K., Punyatrong, K., Suzuki, M., 2001. Altitudinal increase in rainfall in the Mae Chaem watershed, Thailand. J. Meteor. Soc. Jpn. 79, 353-363.

Kuwada, T., Kotake, T., Takeuchi, S., Maximov, T.C., Yoshikawa, K., 2002. Relationships among water dynamics, soil moisture and vapor pressure deficit in a Larix gmelinii stand, eastern boreal Siberia. J. Jpn. For. Soc. 84, 246-254 (in Japanese, with English summary).

Landsberg, J.J., Blanchard, T.W., Warrit, B., 1976. Studies on the movement of water through Apple Trees. J. Exp. Bot. 27, 79-596.

Mabuchi, K., Sato, Y., Kida, H., 2005. Climatic impact of vegetation change in the Asian tropical region. Part I. Case of the northern hemisphere summer. J. Clim. 18, 410-428.

Malhi, Y., Wright, J., 2004. Spatial patterns and recent trends in the climate of tropical rainforest regions. Phil. Trans. R. Soc. Lond. B 359, 311-329.

Marshall, D.C., 1958. Measurement of sap flow in conifers by heat transport. Plant Physiol. 33, 385-396.

Meinzer, F.C., Goldstein, G., Jackson, P., Holbrook, N.M., Gutierrez, M.V., Cavelier, J., 1995. Environmental and physiological regulation of transpiration in tropical forest gap species: the influence of boundary layer and hydraulic properties. Oecologia 101, 514-522.

Meinzer, F.C., Andrade, J.L., Goldstein, G., Holbrook, N.M., Cavelier, J., Wright, S.J., 1999. Partitioning of soil water among canopy trees in a seasonally dry tropical forest. Oecologia 121, 293-301.

Monteith, J.L., Unsworth, M., 1990. Principles of Environmental Physics. Arnold, London.

Myers, N., 1994. Tropical forests: present status and future outlook. Clim. Change 19, 3-32.

Nakagawa, M., Tanaka, K., Nakashizuka, T., Ohkubo, T., Kato, T., Maeda, T., Sato, K., Miguchi, H., Nagamasu, H., Ogino, K., Teo, S., Hamid, A.A., Seng, L.H., 2000. Impact of severe drought associated with the 1997-1998 El Niño in a tropical forest in Sarawak. J. Trop. Ecol. 16, 355-367.

Nepstad, D.C., de Carvalho, C.R., Davidson, E.A., Jipp, P.H., Lefebvre, P.A., Negreiros, G.H., da Silva, D.E., Stone, T.A., Trumbore, S.E., Vieira, S., 1994. The role of deep roots in the hydrological and carbon cycles of Amazonian forests and pastures. Nature 372, 666-669.

Ogawa, H., Yoda, K., Ogino, K., Kira, T., 1965. Comparative ecological studies on three main types of forest vegetation in Thailand. 2. Plant biomass. Nat. Life S.E. Asia 4, 49-80.

O'Grady, A.P., Eamus, D., Hutley, B., 1999. Transpiration increases during the dry season: pattern of tree water use in eucalypt open-forest of northern Australia. Tree Physiol. 19, 591-597.

Pataki, D.E., Oren, R., Smith, W.K., 2000. Sap flux of co-occurring species in a western subalpine forest during seasonal soil drought. Ecology 81, 25572566.

Pinker, R.T., Thompson, O.E., Eck, T.F., 1980. The energy balance of a tropical evergreen forest. J. Appl. Meteorol. 19, 1341-1350.

Prioul, J.L., Chartier, P., 1977. Partitioning of transfer and carboxylation components of intercellular resistance to photosynthetic $\mathrm{CO}_{2}$ fixation: a critical analysis of the methods used. Ann. Bot. 41, 789-800.

R Development Core Team, 2005. R: A Language and Environment for Statistical Computing. R Foundation for Statistical Computing, Vienna, Austria., ISBN 3-900051-07-0http://www.R-project.org.

Richter, H., 1997. Water relations of plants in the field: some comments on the measurement of selected parameters. J. Exp. Bot. 87, 1287-1299.

Roberts, J., Cabral, O.M.R., Fisch, G., Molion, L.C.B., Moore, C.J., Shuttleworth, W.J., 1993. Transpiration from an Amazonian rainforest calculated from stomatal conductance measurements. Agric. For. Met. 65, 175-196.
Roberts, J.M., Gash, J.H.C., Tani, M., Bruijnzeel, L.A., 2005. Controls on evaporation in lowland tropical rainforest. In: Bonell, M., Bruijnzeel, L.A. (Eds.), Forest, Water, and People in the Humid Tropics. Cambridge University Press, Cambridge, pp. 287-313.

Sakuratani, T., 1981. A heat balance method for measuring water flux in the stem of intact plants. J. Agric. Meteorol. 37, 9-17.

Saleska, S.R., et al., 2003. Carbon in Amazon forests: unexpected seasonal fluxes and disturbance-induced losses. Science 32, 1554-1557.

Sri-Ngernyuang, K., Kanzaki, M., Mizuno, T., Noguchi, H., Teejuntuk, S., Sungpalee, C., Hara, M., Yamakura, T., Sahunalu, P., Dhanmanonda, P., Bunyavejchewin, S., 2003. Habitat differentiation of Lauraceae species in a tropical lower montane forest in northern Thailand. Ecol. Res. 18, 1-14.

Swanson, R.H., Whitfield, D.W.A., 1981. A numerical analysis of heat pulse velocity theory and practice. J. Exp. Bot. 32, 221-239.

Takizawa, H., Kubota, J., Kobayashi, T., Tsukamoto, Y., 1996. An experimental study of the variation of water storage with transpiration in Cryptomeria japonica. J. Jpn. For. Soc. 78, 66-73 (in Japanese, with English summary).

Takizawa, H., Suzuki, M., Tanaka, N., Kosaka, I., Yoshifuji, N., Tanaka, K., Tantasirin, C., Tangtham, N., 2001. The general climate at hill evergreen forest of tropical monsoon area in northern Thailand. In: Proceedings of the Fifth International Study Conference GEWEX in Asia and GAME 2. pp. 619-623.

Tanaka, K., Takizawa, H., Tanaka, N., Kosaka, I., Yoshifuji, N., Tantasirin, C., Piman, S., Suzuki, M., Tangtham, N., 2003. Transpiration peak over a hill evergreen forest in northern Thailand in the late dry season: assessing the seasonal changes on evapotranspiration using a multilayer model. J. Geophys. Res. 108, D4533, doi:10.1029/2002JD003028.

Tanaka, K., Takizawa, H., Kume, T., Xu, J., Tantasirin, C., Suzuki, M., 2004. Impact of rooting depth and soil hydraulic properties on the transpiration peak of an evergreen forest in northern Thailand in the late dry season. J. Geophys. Res. 109, D23107, doi:10.1029/2004JD004865.

Tangtham, N., 1974. Preliminary study of the ecosystem of hill evergreen forest in northern Thailand. Ph.D. Thesis. Pa. State Univ., Univ. Park, PA, 65 pp.

Toda, M., Nishida, K., Ohte, N., Tani, M., Musiake, K., 2002. Observations of energy fluxes and evapotranspiration over complex terrestrial land covers in the tropical monsoon environment. J. Meteorol. Soc. Jpn. 80, 465-484.

Tromp-van Meerveld, McDonnell, J.J., 2006. On the interrelations between topography, soil depth, soil moisture, transpiration rates and species distribution at the hillslope scale. Adv. Water Resour. 29, 293-310.

Ueda, M., Shibata, E., 2002. Water status of Hinoki cypress (Chamaecyparis obtusa) under reduced hydraulic conductance estimated from diurnal changes in trunk diameter. Trees 16, 523-528.

Walsh, R.P.D., Newbery, D.M., 1999. The ecoclimatology of Danum, Sabah, in the context of the world's rainforest regions, with particular reference to dry periods and their impact. Phil. Trans. R. Soc. Lond. B 354, 1869-1883.

Wang, C., Weisberg, R.H., 2000. The 1997-98 El Niño evolution relative to previous El Niño events. J. Clim. 13, 488-501.

Yamada, C., Tanaka, N., Suzuki, M., Tantasirin, C., Tangtham, N., 2001. Water budget and runoff characteristics in Kog-Ma experimental watershed, northern Thailand. In: Proceedings of the Fifth International Study Conference GEWEX in Asia and GAME 2. pp. 3-5.

Yoshifuji, N., Kume, T., Tanaka, N., Tantasirin, C., Takizawa, H., Suzuki, M., Tangtham, N., 2001. Comparison of seasonal trend in sap flow rate between deciduous and evergreen trees in northern Thailand. In: Proceedings of the Fifth International Study Conference GEWEX in Asia and GAME 2. pp. 395-399.

Zhang, L., Dawes, W.R., Walker, G.R., 2001. Response of mean annual evapotranspiration to vegetation changes at catchment scale. Water Resour. Res. 37, 701-708. 